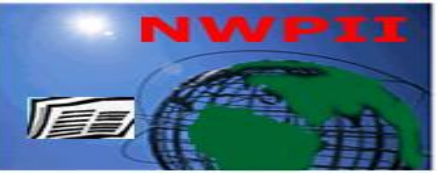

American Journal of Biomedical Sciences

ISSN: 1937-9080

nwpii.com/ajbms

\title{
Sexual Dimorphism in Serum Kisspeptin Level in Experimentally Induced Non Alcoholic Fatty Liver Disease in Adult Albino Rats
}

\author{
Reham Hassan Ibrahim, M.D. and Maha Abdelhamid Fathy, M.D.
}

Medical Physiology Department, Faculty of Medicine, Zagazig University, Egypt

*Corresponding Author

Dr. Reham Hassan Ibrahim

Medical Physiology Department,

Faculty of Medicine,

Zagazig University

Egypt

E-mail: phisiology_lover_4@yahoo.com

Received:22 March 2018; | Revised:28 April 2018; | Accepted: 04 June 2018

\begin{abstract}
Background: non-alcoholic fatty liver disease (NAFLD) pathophysiology is not properly understood, studies have demonstrated gender differences in prevalence of NAFLD and severity of the disease. Insulin resistance (IR) is well known to play a key role in NAFLD pathogenesis. kisspeptin neuropeptide (KISS1) is main regulator of reproduction. It is thought that kisspeptin has a metabolic role outside its function in reproduction, its association with insulin resistance and its effects on insulin secretion have conflicting results, in addition, Kisspeptin signaling has a different effect on metabolism in male and female rats.

Objective: To clarify a possible sexual dimorphism in the interaction between kisspeptin and pathogenesis of high fat diet (HFD) induced NAFLD in adult male and female albino rats. Material and methods: 20 male and 20 female adult albino rats were used. The animals were divided to 4 equal subgroups: group (Ia): control male rats; group (Ib): HFD male rats; group (IIa): control female rats; group (IIb): HFD female rats. In all groups, BMI, kisspeptin serum levels, glucose, insulin (with calculation of HOMA-IR), lipid profile, glucagon, ALT, AST, LH, FSH, progesterone, estradiol (E2) and testosterone were measured and histopathological liver injury scoring was made.

Results: HFD male and female groups (group Ib and group IIb respectively) showed significant increase in BMI, serum glucose, insulin levels, HOMA-IR index, glucagon, TC, TG, LDL, AST, ALT levels with significant decrease in serum HDL in the same groups. However, the percentage of changes in these parameters was higher in male than female rats. Histopathological examination of HFD groups revealed a non- alcoholic steatohepatitis in group $\mathrm{Ib}$ and border line steatosis in group IIb with significantly higher hepatic injury score in group Ib in comparison to group IIb. Serum kisspeptin increased significantly in HFD male group Ib, while it decreased significantly in HFD female group IIb relative to their controls. Moreover group Ib showed a significant increase in serum estradiol, significant decrease in serum testosterone and nonsignificant change in serum progesterone, LH and FSH. In group IIb, a significant increase in serum
\end{abstract}


progesterone level was found, while a non-significant change was found in serum estradiol, testosterone, $\mathrm{LH}$ and FSH. Conclusions: The present study suggested that kisspeptin may play a role in the pathogenesis of NAFLD in male rather than in female rats.

Keywords: NAFLD, Sexual dimorphism, Kisspeptin, Insulin resistance

\section{Introduction}

Non-alcoholic fatty liver disease (NAFLD) is one of the obesity related disorders ${ }^{[1]}$. It is characterized by liver injury from simple steatosis to steatohepatitis which can cause fibrosis and cirrhosis ${ }^{[2]}$. It can also cause hepatic carcinoma ${ }^{[3]}$. Insulin resistance (IR) has a central effect in the pathogenesis of NAFLD, as strong evidence demonstrates that, in NAFLD patients, insulin does not decrease lipolysis to the same degree that it does in healthy individuals ${ }^{[4]}$. Previous reports have demonstrated that, resistance of hormone-sensitive lipase to suppressive effect of insulin in insulinresistant states is the predominant defect responsible for the increased flux of fatty acid from adipose tissue to the liver and stored as triglycride (TG) in the liver ${ }^{[5]}$. TG can be stored as droplets of lipid in hepatocytes and act as a predisposing factor to hepatic steatosis ${ }^{[5]}$. Once hepatic steatosis occurs, it proceeds to steatohepatitis (NASH) by inflammation, dysfunction of mitochondria, oxidative stress caused by reactive oxygen species, lipid oxidation resulting in hepatocyte damage and fibrosis ${ }^{[6]}$. kisspeptin (KISS1) is main regulator of reproduction ${ }^{[7,8]}$. Kisspeptin affects the reproductive axis by directly stimulating gonadotropin-releasing hormone $(\mathrm{GnRH})$ neurons [9]. There are two major kisspeptin neurones: those in hypothalamic anteroventral periventricular nucleus (AVPV) which are responsible for the luteinizing hormone (LH) surge by mediating positive feedback effect of estradiol (E2), and the arcuate kisspeptin population which mediate steroid negative feedback actions on LH secretion ${ }^{[10,11]}$. Although kisspeptin is expressed in many areas of the brain ${ }^{[12]}$, it is also present in some peripheral tissues $[13,14]$ including metabolic tissues like adipose, hepatic and pancreatic tissue ${ }^{[15]}$ which indicates that kisspeptin has other functions outside reproduction. Changes in metabolic signals or energy status affect reproduction and kisspeptin levels ${ }^{[16]}$. In addition, effect of kisspeptin on insulin secretion has controversial results. While some researchers stated that kisspeptin inhibits insulin secretion [17, 18], others reported that kisspeptin stimulates insulin secretion [14, 19]. Moreover, in polycystic ovary syndrome, plasma kisspeptin levels were correlated negatively with insulin resistance ${ }^{[20]}$. However, another study reported no correlation between kisspeptin concentrations and index of insulin resistance ${ }^{[21]}$. Furthermore, Kisspeptin signaling has a sexual dimorphic effect on metabolism, and glucose homeostasis ${ }^{[22]}$. From the above data, it is worth saying that kisspeptin may have a role in the pathogenesis of NAFLD, and this role may be different among male and female as NAFLD is a sexually dimorphic condition.

The aim of this study is to compare kisspeptin level in male and female rats with (HFD) induced NAFLD in relation to different metabolic parameters and sex hormones.

\section{Materials and Methods}

This study was conducted from May 2017 to January 2018 on, 20 male and 20 female adult albino rats (150-180 g), obtained from animal house, Veterinary Medicine Faculty , Zagazig University, and were housed at room temperature with natural dark/light cycle and received food and water. After one week of acclimatization, the animals were divided in to 4 equal subgroups: group (Ia): control male rats; group (Ib): NAFLD male rats; group (IIa): control female rats; group (IIb): NAFLD female rats. Rats in control groups were fed a standard mixed commercial rat laboratory chow $(25.8 \%$ protein, $59.7 \%$ carbohydrate and $14.5 \%$ fat), while rats in NAFLD groups were fed (HFD) $(9.7 \%$ protein, $37.7 \%$ carbohydrate and $53 \%$ fat) for 90 days ${ }^{[23]}$. Diet was obtained from Department of Nutrition, Veterinary Medicine Faculty, Zagazig University. The experimental protocol used in this study was according to the guiding data for the use of research 
animals and were approved by the Institutional Research Board of Faculty of Medicine, Zagazig University.

Anthropometric measures: Measuring body weight: The animal was put in closed plastic container and weighed one day before the experiment and at the last day. The results were recorded for each labeled rat. Measuring rat length: by metal ruler, nose to anus length was measured. Calculating BMI index: Body mass index (BMI) equals body weight $(\mathrm{g}) /$ length2 $(\mathrm{cm} 2)$, this index can be used as an indicator of obesity where the cut off value of obesity BMI is more than $0.68 \mathrm{~g} / \mathrm{cm} 2$ [24].

Blood collection: scarification of animals at the end of experimental period under light ether anesthesia after overnight fasting, and blood samples were obtained by decapitation of all rats, blood samples from female rats obtained during estrus stage which was determined by vaginal smear, blood was collected in clean centrifuge tubes and leaved to clot, then centrifuged at 3000 r.p.m. for 15 minutes The supernatant serum was pipetted off using fine tipped automatic pipettes and stored deep frozen at -20 until assayed ${ }^{[25]}$. Biochemical assay: Serum kisspeptin levels were analyzed by a commercial enzyme immunoassay (EIA) kit (Phoenix Pharmaceuticals Inc., Burlingame, California, USA). ${ }^{[21]}$. Serum glucose level: According to Tietz et al. [26] using glucose enzymatic (GOD-PAP)-liquizyme Kits (Biotechnology, Egypt). Serum insulin level: according to Temple et al. ${ }^{[27]}$, by a solid phase enzyme amplified sensitivity immunoassay. HOMA-IR was assessed by homeostasis model assessment (where HOMA= fasting serum insulin $(\mu \mathrm{IU} / \mathrm{mL}) \times$ [fasting serum glucose $(\mathrm{mmol} / \mathrm{L}) / 22.5$ ] [28, 29]. Glucagon levels: by glucagon ELISA kit (Cat. No: Rab 0202; Sigma AldichChemieGmBH, St.Louis, USA) [30]. Serum testosterone level: according to Tietz et al. ${ }^{[26]}$ using rat testosterone ELISA kit: (Catalog Number: 2011-11-5126, shanghai, China). Serum follicular stimulating hormone (FSH) level: according to Robertson [31] using rat follicle-Stimulating Hormone (FSH) ELISA kit (Catalog Number: 2011-11-0183, shanghai, China). Serum Luteinizing hormone (LH) level: according to Robertson [31] using rat luteinizing hormone (LH) ELISA kit (Catalog
Number: 2011-11-0180, China). Estradiol (E2) and Progesterone level: according to March et al. [32], using ELISA rat kits: BC-1029 and BC-1115, respectively, BioCheck Inc 323 Vintage Park, CA 94404. Serum aspartate aminotransferase (AST), alanine aminotransferase (ALT), were analyzed by an automatic biochemical analyzer using standard enzymatic techniques ${ }^{[33]}$. Serum total cholesterol (TC) level: according to Tietz et al. ${ }^{[26]}$ using rat cholesterol enzyme-linked immunosorbent assay kit, (BioSource Europe S.A.-Rue de 1' Industrie, 8-B1400 Nivelles-Belgium). Serum triglycerides (TG) level: using rat triglycerides enzyme-linked immunesorbent assay kit, (BioSource Europe S.A.Rue de 1' Industrie, 8-C- 1150 Nivelles- Belgium according to Fossati and Prencipe ${ }^{[34]}$. Serum high density lipoproteins (HDL) levels: according to Albers et al. ${ }^{[35]}$ using rat HDL- cholesterol enzymelinked immunosorbent assay kit, (BioSource Europe S.A.-Rue de 1' Industrie, 8-A- 1340 NivellesBelgium). Serum low density lipoproteins (LDL) levels: according to Friedwald et al ${ }^{[36]}$, LDL was calculated as follows: $\mathrm{LDL}=\mathrm{TC}-\mathrm{HDL}-\mathrm{TG} / 5$.

Liver histopathology: All removed livers were fixed in $10 \%$ buffered formalin solution for duration of 48-60 hours. After this, tissue samples were processed through ethyl alcohol and xylene series, and put in paraffine blocks. Liver specimens were cut $(5 \mu \mathrm{m}$ thick), then stained with hematoxylin and eosin ${ }^{[37]}$. An expert pathologist evaluated the stained samples in a blind fashion using Light microscope with camera attachment and scored them. The histopathological scoring of NAFLD followed the NAFLD Activity Score (NAS) ${ }^{[38]}$. The score is steatosis $(0=<5 \%, 1=5 \%-33 \%, 2=$ $34 \%-66 \%, 3=>66 \%)$, lobular inflammation $(0=$ no foci, $1=<2$ foci, $2=2-4$ foci, $3=>4$ foci), and ballooning $(0=$ none, $1=$ rare or few, $2=$ many or prominent). Fibrosis stages: $0=$ none, $1=$ perisinusoidal or periportal fibrosis, $2=$ perisinusoidal and portal/periportal fibrosis, $3=$ bridging fibrosis and $4=$ cirrhosis. The score of (NAS $\geqslant 5$ was defined as non alcoholic steatohepatitis (NASH), $2<$ NAS $<5$ was defined as borderline and NAS $\leqslant 2$ was defined as simple steatosis), cirrhosis was defined as grade 4 fibrosis plus other features of NAS ${ }^{[39]}$. 
Statistical analysis: The data presented as mean \pm SD and analyzed statistically by using SPSS program (version 18 for windows) (SPSS Inc. Chicago, IL, USA). Independent $\mathrm{T}$ test was used to compare means of groups. The correlations between parameters were analyzed using Pearson's correlation. $\mathrm{P}$ values $<0.05$ considered significant.

\section{Results}

In group Ib (HFD-fed male rats), there was a significant increase in BMI, serum glucose, insulin levels, HOMA-IR index, TC, TG, LDL, AST, ALT levels in comparison to control $(\mathrm{P}<0.001)$. However, there was a significant decrease in serum HDL in the same group $(\mathrm{P}<0.01)$ [Table 1]. We found a significant increase in serum kisspeptin and estradiol $(\mathrm{P}<0.01)$, while there was a significant decrease in serum testosterone $(\mathrm{P}<0.01)$. However, there was non-significant change in serum FSH, LH and progesterone in comparison to control $(\mathrm{p}>0.05)$ [Table 2].

In group IIb (HFD-fed female rats), there was a significant increase in serum glucose, TG, LDL $(\mathrm{P}<0.001)$ and in BMI, HOMA-IR index, TC, AST, ALT levels $(\mathrm{P}<0.01)$ and in serum insulin $(\mathrm{P}<0.05)$ in comparison to control. However, there was a significant decrease in serum HDL in the same group $(\mathrm{P}<0.05)$, the percentage of change in these parameters in group IIb in relation to its control group IIa was lower than percentage of change in the same parameters in group $\mathrm{Ib}$ in relation to its control group Ia [Table 1].
In addition, in group IIb (HFD-fed female rats), there was a significant decrease in serum kisspeptin $(\mathrm{P}<0.001)$, while there was a significant increase in serum progesterone $(\mathrm{P}<0.05)$. However, there was non-significant change in serum FSH, LH, testosterone and estradiol in comparison to control $(\mathrm{p}>0.05)$ [Table 2].

Regarding correlation of kisspeptin with metabolic parameters and sex hormones, in group Ib, Serum kisspeptin showed a significant positive correlation with BMI $(\mathrm{P}<0.05)$, serum glucose $(\mathrm{P}<0.05)$ glucagon $(\mathrm{P}<0.05)$, TC $(\mathrm{P}<0.05)$, TG $(\mathrm{P}<0.01)$, LDL $(\mathrm{p}<0.01)$, AST $(\mathrm{P}<0.05)$ and ALT $(p<0.01)$. On the other hand, in group IIb, serum kisspeptin didn' $t$ correlate with any of measured parameters $(\mathrm{p}>0.05)$.

Hepatic histopathological examination revealed normal liver tissue with normal architecture,normal hepatocyte and normal central vein in both groups Ia (control male rats) [Fig 1] and IIa (control female rats) [Fig 3], HFD induced non- alcoholic steatohepatitis in group Ib and border line steatosis in group IIb. There was a significant increase in hepatic injury score in group $\mathrm{Ib}(6.2 \pm$ $0.77)$ in comparison to group IIb $(3.8 \pm 0.51)$ $(\mathrm{p}<0.001)$ with a significant positive correlation between kisspeptin level and hepatic injury score in group $\mathrm{Ib} \quad(\mathrm{p}<0.05)$, but there is no significant correlation between kisspeptin level and hepatic injury score in group IIb (p>0.05) [Fig $2,4 \&$ Table 3].

Table 1: Metabolic profile of all studied groups

\begin{tabular}{|c|c|c|c|c|}
\hline $\begin{array}{c}\text { GROUPS } \\
\text { PARAMETERS }\end{array}$ & Group Ia & Group Ib & Group IIa & Group IIb \\
\hline Body Mass Index $\left(\mathrm{g} / \mathrm{cm}^{2}\right)$ & $\begin{array}{l}0.58 \pm 0.06 \\
\mathrm{r}=+0.524\end{array}$ & $\begin{array}{c}0.81 \pm 0.07^{\mathrm{a} * *} \\
\mathrm{r}=+0.915^{*}\end{array}$ & $\begin{array}{l}0.47 \pm 0.04 \\
\mathrm{r}=+0.502\end{array}$ & $\begin{array}{c}0.61 \pm 0.07^{b^{* *}} \\
r=+0.544\end{array}$ \\
\hline$\%$ of change & & $39 \%$ & & $29 \%$ \\
\hline Glucose(mg/dl) & $\begin{array}{c}93 \pm 6.6 \\
r=+0.482 \\
\end{array}$ & $\begin{array}{l}188 \pm 3.1^{\mathrm{a}^{* * *}} \\
\mathrm{r}=+0.752^{*}\end{array}$ & $\begin{array}{c}87 \pm 2.5 \\
\mathrm{r}=+0.321\end{array}$ & $\begin{array}{c}133 \pm 4.2^{b^{* * *}} \\
\mathrm{r}=+0.452\end{array}$ \\
\hline$\%$ of change & & $102 \%$ & & $52 \%$ \\
\hline Insulin $(\mu \mathrm{IU} / \mathrm{ml})$ & $\begin{array}{c}11.93 \pm 1.77 \\
r=-0.569\end{array}$ & $\begin{array}{c}21.33 \pm 6.4^{\mathrm{a}^{* * *}} \\
\mathrm{r}=+0.115\end{array}$ & $\begin{array}{c}5.02 \pm 0.91 \\
r=-0.423\end{array}$ & $\begin{array}{l}8.6 \pm 0.2^{b^{*}} \\
r=+0.399\end{array}$ \\
\hline$\%$ of change & & $90 \%$ & & $71 \%$ \\
\hline HOMA-IR & $\begin{array}{c}2,5 \pm 0.07 \\
\mathrm{r}=+0.422\end{array}$ & $\begin{array}{c}9,7 \pm 1.03^{\mathrm{a} * *} \\
\mathrm{r}=+0.299\end{array}$ & $\begin{array}{l}1.07 \pm 0.25 \\
\mathrm{r}=+0.358\end{array}$ & $\begin{array}{c}2.62 \pm 0.7^{\mathrm{b} * *} \\
\mathrm{r}=+0.402\end{array}$ \\
\hline
\end{tabular}




\begin{tabular}{|c|c|c|c|c|}
\hline$\%$ of change & & $288 \%$ & & $144 \%$ \\
\hline Glucagon (ng/ml) & $\begin{array}{l}200 \pm 2.62 \\
\mathrm{r}=+0.602\end{array}$ & $\begin{array}{l}320 \pm 2.3^{\mathrm{a} * * *} \\
\mathrm{r}=+0.847^{*}\end{array}$ & $\begin{array}{c}110 \pm 3.4 \\
\mathrm{r}=+0.558\end{array}$ & $\begin{array}{l}150 \pm 3.5^{b^{* *}} \\
r=+0.531\end{array}$ \\
\hline$\%$ of change & & $60 \%$ & & $36 \%$ \\
\hline Total Cholesterol (mg/dl) & $\begin{array}{c}89.27 \pm 10.62 \\
\mathrm{r}=+0.342\end{array}$ & $\begin{array}{c}152 \pm 20.23^{\mathrm{a} * * *} \\
\mathrm{r}=+0.892^{*}\end{array}$ & $\begin{array}{l}77.66 \pm 13.1 \\
\mathrm{r}=+0.228\end{array}$ & $\begin{array}{c}105.5 \pm 11.08^{* *} \\
r=+0.366\end{array}$ \\
\hline$\%$ of change & & $70 \%$ & & $36 \%$ \\
\hline Total Triglycride (mg/dl) & $\begin{array}{c}65.50 \pm 15.35 \\
\mathrm{r}=+0.381\end{array}$ & $\begin{array}{l}140.83 \pm 11.59^{\mathrm{a}^{* * *}} \\
\mathrm{r}=+0.978^{* *}\end{array}$ & $\begin{array}{l}64.16 \pm 4.13 \\
\mathrm{r}=+0.407\end{array}$ & $\begin{array}{c}103.01 \pm 8.91^{\mathrm{b}^{* * *}} \\
\mathrm{r}=+0.344\end{array}$ \\
\hline$\%$ of change & & $155 \%$ & & $60 \%$ \\
\hline Low Density Lipoprotein (mg/dl) & $\begin{array}{c}35 \pm 8.66 \\
\mathrm{r}=+0.264\end{array}$ & $\begin{array}{l}93 \pm 12.14^{\mathrm{a} * * *} \\
\mathrm{r}=+0.971^{* *}\end{array}$ & $\begin{array}{c}26.96 \pm 12.45 \\
\mathrm{r}=+0.298\end{array}$ & $\begin{array}{l}52.79 \pm 15.11^{\mathrm{b}^{* * *}} \\
\mathrm{r}=+0.422\end{array}$ \\
\hline$\%$ of change & & $165 \%$ & & $100 \%$ \\
\hline High Density Lipoprotein (mg/dl) & $\begin{array}{l}41.83 \pm 0.89 \\
\mathrm{r}=-0.455\end{array}$ & $\begin{array}{c}31.56 \pm 1.57^{\mathrm{a} * *} \\
\mathrm{r}=-0.521\end{array}$ & $\begin{array}{c}38.54 \pm 1.42 \\
\mathrm{r}=-0.289\end{array}$ & $\begin{array}{c}33.85 \pm 2.43^{b^{*}} \\
r=-0.366\end{array}$ \\
\hline$\%$ of change & & $25 \%$ & & $11.5 \%$ \\
\hline $\begin{array}{c}\text { Serum Aspartate Aminotransferase } \\
(\mathrm{AST})(\mathrm{u} / \mathrm{l})\end{array}$ & $\begin{array}{l}48.55 \pm 1.9 \\
\mathrm{r}=+0.393\end{array}$ & $\begin{array}{c}78.24 \pm 2.37^{\mathrm{a} * * *} \\
\mathrm{r}=+0.811^{*}\end{array}$ & $\begin{array}{c}55 \pm 1.22 \\
\mathrm{r}=+0.311\end{array}$ & $\begin{array}{c}68.2 \pm 0.3^{\mathrm{b} * *} \\
\mathrm{r}=+0.410\end{array}$ \\
\hline \% of change & & $61 \%$ & & $23 \%$ \\
\hline $\begin{array}{c}\text { Serum Alanine Aminotransferase } \\
\text { (ALT) }(u / l)\end{array}$ & $\begin{array}{c}24.8 \pm 1.07 \\
\mathrm{r}=+0.412\end{array}$ & $\begin{array}{c}44.27 \pm 0.96^{\mathrm{a} * * *} \\
\mathrm{r}=+0.829^{* *}\end{array}$ & $\begin{array}{c}18 \pm 0.48 \\
\mathrm{r}=+0.388\end{array}$ & $\begin{array}{c}30.2 \pm 0.3^{\mathrm{b} * *} \\
\mathrm{r}=+0.399\end{array}$ \\
\hline \% of change & & $83 \%$ & & $66 \%$ \\
\hline
\end{tabular}

Group Ia (control male rats), Group Ib (HFD-fed male rats), Group IIa(control female rats), Group IIb (HFD-fed female rats) $\mathrm{a}=$ vs group Ia; $\mathrm{b}=$ vs group IIa; $\mathrm{r}=$ correlation coefficient versus kisspeptin level; *= significant $(\mathrm{P}<0.05)$; $* *=$ significant $(\mathrm{P}<0.01) ; * * *=$ significant $(\mathrm{P}<0.001)$

Table 2: Hormonal profile of all studied groups

\begin{tabular}{|c|c|c|c|c|}
\hline PARAMETERS & Group Ia & Group Ib & Group IIa & Group IIb \\
\hline Kisspeptin (ng\ml) & $1.5 \pm 0.13$ & $2.1 \pm 0.08^{* *}$ & $2.4 \pm 0.3$ & $1.6 \pm 0,2^{* * *}$ \\
\hline $\begin{array}{l}\text { FollicleStimulating } \\
\text { Hormone (ng/ml) }\end{array}$ & $\begin{array}{c}8 \pm 0.05 \\
\mathrm{r}=+0.499\end{array}$ & $\begin{array}{c}8.7 \pm 0.03 \\
\mathrm{r}=+0.554\end{array}$ & $\begin{array}{l}17.8 \pm 0.12 \\
\mathrm{r}=+0.433\end{array}$ & $\begin{array}{c}18 \pm 1.36 \\
\mathrm{r}=+0.624\end{array}$ \\
\hline $\begin{array}{c}\text { Luteinizing Hormone } \\
\text { (ng/ml) }\end{array}$ & $\begin{array}{c}2.2 \pm 0.08 \\
\mathrm{r}=+0.318\end{array}$ & $\begin{array}{c}3 \pm 0.13 \\
\mathrm{r}=+0.395\end{array}$ & $\begin{array}{c}3.5 \pm 0.3 \\
\mathrm{r}=+0.485\end{array}$ & $\begin{array}{c}4 \pm 0.18 \\
r=+0.522\end{array}$ \\
\hline Testosterone (ng/ml) & $\begin{array}{l}3.13 \pm 0.34 \\
r=+0.425\end{array}$ & $\begin{array}{c}1.74 \pm 0.39^{\mathrm{a} * *} \\
\mathrm{r}=+0.477\end{array}$ & $\begin{array}{c}0.96 \pm 0.6 \\
\mathrm{r}=+0.492\end{array}$ & $\begin{array}{c}0.99 \pm 1.2 \\
\mathrm{r}=+0.514\end{array}$ \\
\hline Estradiol (pg/ml) & $\begin{array}{l}5.14 \pm 1.36 \\
\mathrm{r}=+0.559\end{array}$ & $\begin{array}{c}11.4 \pm 3.24^{\mathrm{a}}{ }^{* *} \\
\mathrm{r}=0.580\end{array}$ & $\begin{array}{c}18.8 \pm 5.2 \\
\mathrm{r}=+0.548\end{array}$ & $\begin{array}{c}20.6 \pm 2.6 \\
\mathrm{r}=+0.599\end{array}$ \\
\hline progesterone (ng/ml) & $\begin{array}{c}2.3 \pm 0.3 \\
\mathrm{r}=+0.449\end{array}$ & $\begin{array}{c}2.5 \pm 0.4 \\
\mathrm{r}=+0.488\end{array}$ & $\begin{array}{c}9.6 \pm 0.6 \\
r=+0.450\end{array}$ & $\begin{array}{l}14.2 \pm 0.3^{\mathrm{b}^{*}} \\
\mathrm{r}=+0.582\end{array}$ \\
\hline
\end{tabular}

Group Ia (control male rats), Group Ib (HFD-fed male rats), Group IIa(control female rats), Group IIb (HFD-fed female rats) $\mathrm{a}=$ vs group Ia; $\mathrm{b}=$ vs group IIa; $\mathrm{r}=$ correlation coefficient versus kisspeptin level; $*=$ significant $(\mathrm{P}<0.05)$; $* *=$ significant $(\mathrm{P}<0.01) ; * * *=$ significant $(\mathrm{P}<0.001)$ 


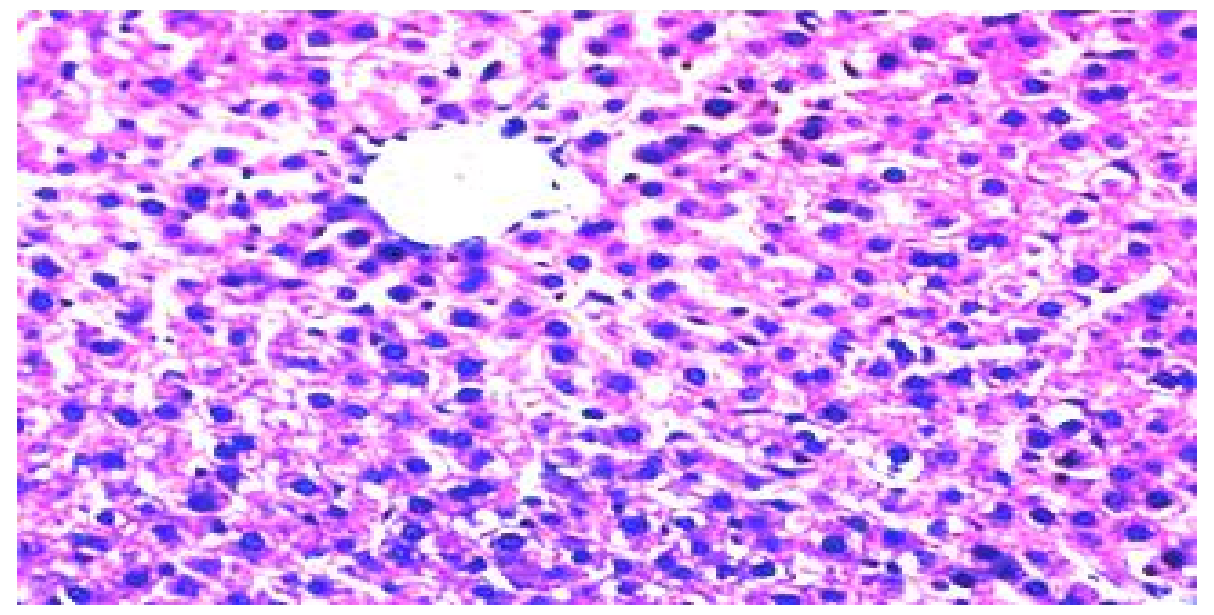

Fig 1: Photomicroscopic picture of isolated liver tissue in group Ia, stained with $\mathbf{H} \& \mathbf{E}$ and viewed under high power magnification $\mathbf{x 4 0 0}$ showing normal liver tissue with normal architecture, normal hepatocyte, and normal central vein

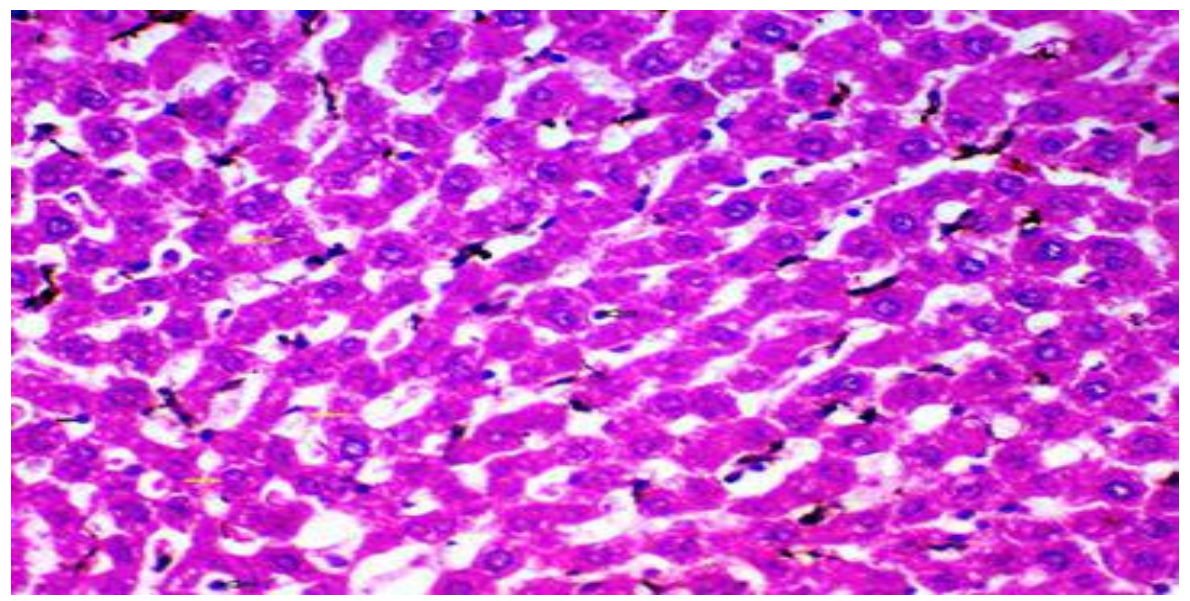

Fig 2:Photomicroscopic picture of isolated liver tissue in group Ib, stained with $\mathrm{H} \& \mathrm{E}$ and viewed under high power magnification $\mathbf{x} 400$ showing liver with non alcoholic steatohepatitis (NASH); fatty infiltration, foci of inflammatory infiltration and ballooning degeneration

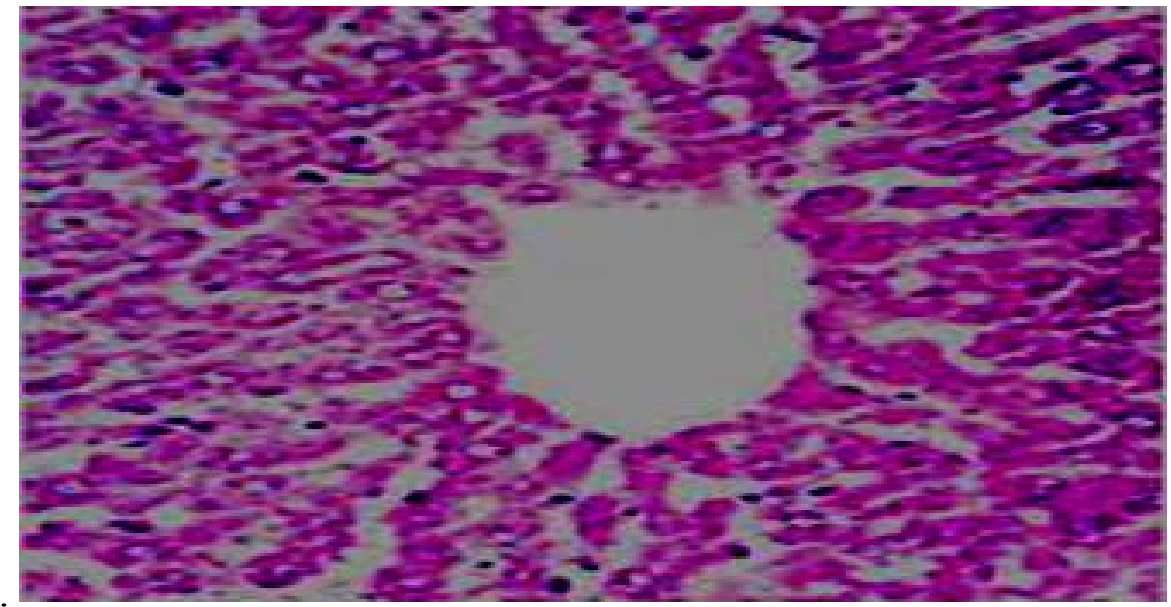

Fig 3: Photomicroscopic picture of isolated liver tissue in group IIa, stained with $\mathbf{H} \& \mathbf{E}$ and viewed under high power magnification $\mathbf{x} 400$ showing normal liver tissue with normal architecture, normal hepatocyte and normal central vein 


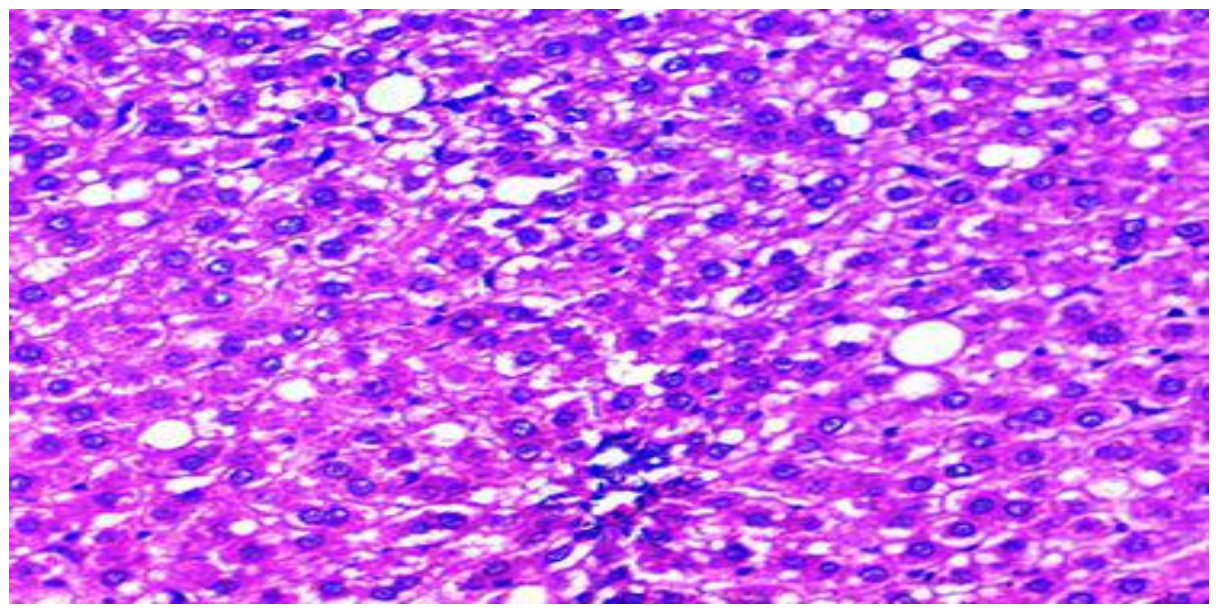

Fig 4: Photomicroscopic picture of isolated liver tissue in group IIb, stained with $\mathrm{H} \& \mathrm{E}$ and viewed under high power magnification $\mathbf{x 4 0 0}$ showing liver with border line steatosis; fatty deposition and mild inflammation

Table 3: Histopathological scoring of liver injury induced by HFD

\begin{tabular}{|l|c|c|c|c|}
\hline GROUPS & Group Ia & Group Ib & Group IIa & Group IIb \\
\hline $\begin{array}{l}\text { Hepatic injury } \\
\text { score }\end{array}$ & 0 & $\begin{array}{c}6.2 \pm 0.77^{\mathrm{a}^{* * *}} \\
\mathrm{r}=0.833^{*}\end{array}$ & 0 & $3.8 \pm 0.51^{\mathrm{a} \mathrm{b}^{* * *}}$ \\
$\mathrm{r}=0.484$
\end{tabular}

Group Ia (control male rats), Group Ib (HFD-fed male rats), Group IIa(control female rats), Group IIb (HFD-fed female rats) $a=$ vs group Ia; $b=$ vs group $I b ; r=$ correlation coefficient versus kisspeptin level; *=significant $(P<0.05)$; $* *=$ significant $(\mathrm{P}<0.01) ; * *=$ significant $(\mathrm{P}<0.001)$;

\section{Discussion}

The current study indicates that high-fat diet induced NAFLD in group $\mathrm{Ib}$ and $\mathrm{IIb}$. In both groups HFD caused obesity as the rise in total cholesterol, LDL and triglycerides was associated with significant increase in body mass index. Moreover, it increased serum glucose, serum insulin and insulin resistance. These results are in line with those of Sjoholm et al. ${ }^{[40]}$ and Eisinger, et al. ${ }^{[41]}$ who noticed that HFD can cause development of many features of metabolic syndrome, disturbance in lipid metabolism and increased insulin resistance lead to development of NAFLD ${ }^{[4]}$, the percentage of increase in these parameters was higher in male than in female, this data is in line with the results of Estrany et al ${ }^{[42-43]}$ and Nickelson et al, ${ }^{[44]}$ who stated that females tend to be less susceptible to many of the deleterious effects of HFD intake. In addition, plasma ALT, AST levels were increased, these results agree with those of Kurek et al. ${ }^{[45]}$ who reported that rats with NAFLD were characterized by significantly elevated serum ALT and AST, which is a sign of a liver lesion, these manifestations were confirmed by histopathological changes in the form of development of NASH in HFD fed male group indicated by fatty infiltration and foci of inflammatory infiltration represented by spotty necrosis, and ballooning degeneration. On the other hand, hepatic histopathological examination in HFD fed female groups showed border line steatosis in the form of macrovesicular fatty infiltration with mild inflammation but without cellular necrosis and accompanied by less increase in ALT and AST compared with male group, these finding are in accordance with those of Kamada et al. ${ }^{[46]}$ and Yatsuji et al. ${ }^{[47]}$.

Kisspeptin is expressed in a number of brain areas that do not contain GnRH ${ }^{[15]}$, as well as in several peripheral tissues each of which might contribute to circulating kisspeptin ${ }^{[48,49]}$, such as liver, pancreas and adipose tissue ${ }^{[13]}$ placenta, pituitary gland, testis and ovary $[50,51,52]$. In the current study, we found a sexually dimorphic difference in kisspeptin level, as high-fat diet (HFD)-induced obese male rats showed increased serum kisspeptin level as compared to their control and was correlated positively and significantly with BMI, serum glucose, TC, TG, and LDL levels, these findings are supported by those of Zhu et al. 
[53] who noticed that kisspeptin was correlated positively with BMI, , TC, TG, and LDL levels and Andreozzi et al. ${ }^{[21]}$ who reported that kisspeptin was correlated positively with serum glucose. The increased serum kisspeptin level might be due to elevation of serum glucagon, it was shown that in HFD induced obesity, glucagon stimulates hepatic expression of kisspeptin which affect pancreatic B cell to suppress insulin secretion ${ }^{[18]}$.

Furthermore, kisspeptin inhibits glucosestimulated insulin secretion from cultured islets at nanomolar concentrations ${ }^{[54]}$. In addition, increased liver kisspeptin leads to reduced insulin-suppressing effect on hepatic glucose production that contributes to hepatic lipogenesis [55], and reduced insulinsuppressing effect on lipolysis ${ }^{[4]}$. It is interesting that, kisspeptin was reported to increase lipolysis and enhanced expression of hormone sensitive lipase in isolated rat adipocytes ${ }^{[56]}$. Because of increased lipolysis of peripheral fats stored in white adipose tissue that flow to the liver as plasma nonesterified fatty acids and transformed to triglycride (TG) ${ }^{[5]}$. TG can then be stored as droplets of lipids in hepatocytes and act as a risk factor for development of hepatic steatosis ${ }^{[6]}$. In addition, increased lipolysis leads to FFAs increase, this impair insulin signaling pathway and result in insulin resistance [57]. Furthermore, Kisspeptin increased cholesterol [58] which causes liver inflammation in mice susceptible to NASH ${ }^{[59]}$. Moreover, kisspeptin stimulated mRNA expression of tumor necrosis factor a (TNF a ), interleukin-6 (IL-6) and monocyte chemotactic protein-1 (MCP-1) [60], secretion of these pro-inflammatory mediators lead to hepatic inflammation and predisposed to hepatic steatohepatitis, as those cytokines activate several serine kinases, including I $к$ B kinase (IKK) [61], this kinase was shown to inhibit insulin action by stimulating the phosphorylation of serine residues of the insulin signaling pathway ${ }^{[62]}$.

Kisspeptin is a vital component for regulation of GnRH secretion. As such, it has been a focus for the central pathway responsible for conveying homeostatic information to $\mathrm{GnRH}$ neurons given its potent role in stimulating the HPG axis. Kisspeptin neurons in the arcuate nucleus (ARC) are associated with the negative feedback regulation of $\mathrm{GnRH}$, in a variety of species including humans ${ }^{[63]}$ and rats ${ }^{[64]}$, this effect is mediated by estrogenic receptor (ER a ) ${ }^{[65]}$ and progesterone receptor ${ }^{[66]}$ in females, and by contributions from both ER a and androgenic receptor in males ${ }^{[67]}$.

Another possible cause that may contribute to increased kisspeptin level in obese male rats is increased Kisspeptin mRNA expression in the hypothalamic (ARC) nucleus as reported by many investigators $[13,68,69]$. Obesity was associated with decrease in serum total testosterone $(\mathrm{T})$ and increases in estradiol (E2) levels [70, 71], which concurs with our results. These inverse changes in testosterone and estradiol levels may be a consequence of the rise in aromatase levels expressed at high levels in visceral fat and males have more aromatase activity than females ${ }^{[72]}$. The increased kisspeptin in the HFD male group could be explained by decreased testosterone ${ }^{[66]}$, because kisspeptin expression in the ARC is inhibited by increased sex steroids [66]. However, inspite of negative feedback between estrogen and kisspeptin, the increased estrogen reported in HFD male group may be unable to cause decrease in kisspeptin expression in the ARC, this conflict might be explained by a previous finding that, HFD increased palmitic acid (PA) in male mice CNS, which cause inflammation and reduced estrogen receptor number in hypothalamic neurons and ARC ${ }^{[73]}$. Moreover, adipose tissue may contribute to increased serum kisspeptin in obese male rats as a positive correlation between Kiss mRNA in visceral adipose tissue and BMI was reported ${ }^{[74]}$.

On the contrary, the current study found decreased serum kisspeptin in (HFD)-induced obese female rats, as compared to their control and there was no significant correlation with BMI or any of the metabolic parameters which concurs with those of Rafique \& Latif ${ }^{[75]}$ and Yerlikaya et al. ${ }^{[76]}$ who stated that kisspeptin was not correlated with BMI. The decreased serum kisspeptin might be due to decreased hypothalamic Kiss mRNA and the number of kisspeptin-immunoreactive cells in HFDinduced obese female rats ${ }^{[68,77]}$. Moreover, the high progesterone level stated in this study may provide inhibitory effect on kisspeptin secretion in ARC as reported by Goodman et al. ${ }^{[78]}$ and they stated that, local antagonism of receptors of progesterone in the ARC interfered with the action of progesterone in reducing kisspeptin level. 
Moreover, it was reported that, in HFDinduced obese female rats, ovarian kisspeptin was down-regulated during proestrus and estrus stages of rat reproductive cycle. More specifically, the immunoreactivity of kisspeptin was greatly reduced in theca cells in the antral and preovulatory follicles [79]. Furthermore, in HFD induced obesity in Wistar rats, a decrease in Kiss 1 mRNA was found in subcutaneous fat which is more predominant in female ${ }^{[80,81,13]}$. All these factors may participate in decreased serum kisspeptin in (HFD)-induced obese female rats observed in this study. It is interesting that elevation of serum glucagon observed in HFD induced obese female rats which was reported to stimulate hepatic expression of kisspeptin ${ }^{[18]}$ might not be effective enough to increase serum kisspeptin in female rats, as a sex difference in serum glucagon concentration was reported to be approximately two fold higher in normal-weight or obese male than in normal-weight or obese female ${ }^{[82]}$.

\section{Conclusion}

HFD induced steatohepatits in obese male rats associated with an increase in serum kisspeptin level that was correlated with metabolic parameters which predispose to the disease, while in obese female rats, HFD induced only border line steatosis associated with a decrease in serum kisspeptin level which indicates a possible role for kisspeptin in the pathogenesis on NAFLD in male rather than in female rat.

\section{Declaration of interest statement}

The authors declare that there is no conflict of interests regarding the publication of this paper.

\section{References}

1 Rinella, ME. Nonalcoholic fatty liver disease: a systematic review. JAMA, 2015, 313, 2263 2273.

2 Brunt EM, Janney CG, Di Bisceglie AM, Neuschwander-Tetri BA, Bacon BR. Nonalcoholic steatohepatitis: a proposal for grading and staging the histological lesions. Am J Gastroenterol 1999; 94(9): 2467-2474
[PMID: 10484010

DOI: $\quad \underline{10.1111 / \mathrm{j} .1572-}$ 0241.1999.01377.x]

3 Reeves HL, Zaki MY, Day CP. Hepatocellular Carcinoma in Obesity, Type 2 Diabetes, and NAFLD. Dig Dis Sci 2016; 61(5): 1234-1245 [PMID: 26921078 DOI: 10.1007/s10620-0164085-6]

4 Sanyal AJ, Campbell-Sargent C, Mirshahi F, Rizzo WB, Contos MJ, Sterling RK, Luketic VA, Shiffman ML, Clore JN. Nonalcoholic steatohepatitis: association of insulin resistance and mitochondrial abnormalities. Gastroenterology 2001; 120(5): 1183-1192 [PMID: $11266382 \quad$ DOI: 10.1053/gast.2001.23256]

5 Sanyal AJ, Campbell-Sargent C, Mirshahi F, Rizzo WB, Contos MJ, Sterling RK, Luketic VA, Shiffman ML, Clore JN. Nonalcoholic steatohepatitis: association of insulin resistance and mitochondrial abnormalities. Gastroenterology 2001; 120(5): 1183-1192 [PMID: $11266382 \quad$ DOI: 10.1053/gast.2001.23256]

6 Day CP, James OF. Steatohepatitis: a tale of two "hits"? Gastroenterology 1998; 114(4): 842-845 [PMID: 9547102]

7 Lapatto R, Pallais JC, Zhang D, Chan YM, Mahan A, Cerrato F, Le WW, Hoffman GE, Seminara SB. Kiss 1-/- mice exhibit more variable hypogonadism than Gpr54-/- mice. Endocrinology 2007; 148(10): 4927-4936 [PMID: 17595229 DOI: 10.1210/en.20070078]

8 Topaloglu AK, Tello JA, Kotan LD, Ozbek MN, Yilmaz MB, Erdogan S, Gurbuz F, Temiz F, Millar RP, Yuksel B. Inactivating KISS1 mutation and hypogonadotropic hypogonadism. N Engl J Med 2012; 366(7): 629-635 [PMID: 22335740 DOI: $10.1056 /$ NEJMoa1111184]

9 Ronnekleiv OK, Kelly MJ. Kisspeptin excitation of GnRH neurons. Adv Exp Med Biol 2013; 784: 113-131 [PMID: 23550004 PMCID: PMC4019505 DOI: 10.1007/978-14614-6199-96]

10 Navarro VM, Gottsch ML, Chavkin C, Okamura H, Clifton DK, Steiner RA. Regulation of gonadotropin-releasing hormone secretion by kisspeptin/dynorphin/neurokinin $\mathrm{B}$ neurons in the arcuate nucleus of the mouse. 
J Neurosci 2009; 29(38): 11859-11866 [PMID: 19776272 PMCID: PMC2793332 DOI: 10.1523/JNEUROSCI.1569-09.2009]

$11 \mathrm{Hu} \mathrm{MH}, \mathrm{Li}$ XF, McCausland B, Li SY, Gresham R, Kinsey-Jones JS, Gardiner JV, Sam AH, Bloom SR, Poston L, Lightman SL, Murphy KG, O'Byrne KT. Relative Importance of the Arcuate and Anteroventral Periventricular Kisspeptin Neurons in Control of Puberty and Reproductive Function in Female Rats. Endocrinology 2015; 156(7): 2619-2631 [PMID: 25875299 PMCID: PMC4475719 DOI: 10.1210/en.2014-1655]

12 Lehman MN, Hileman SM, Goodman RL. Neuroanatomy of the kisspeptin signaling system in mammals: comparative and developmental aspects. Adv Exp Med Biol 2013; 784: 27-62 [PMID: 23550001 PMCID: PMC4059209 DOI: $10.1007 / 978-1-4614-$ 6199-9 3]

13 Brown RE, Imran SA, Ur E, Wilkinson M. KiSS-1 mRNA in adipose tissue is regulated by sex hormones and food intake. Mol Cell Endocrinol 2008; 281(1-2): 64-72 [PMID: 18069123 DOI: 10.1016/j.mce.2007.10.011]

14 Hauge-Evans AC, Richardson CC, Milne HM, Christie MR, Persaud SJ, Jones PM. A role for kisspeptin in islet function. Diabetologia 2006; 49(9): 2131-2135 [PMID: 16826407 DOI: 10.1007/s00125-006-0343-z]

15 Herbison AE, de Tassigny $\mathrm{X}$, Doran J, Colledge WH. Distribution and postnatal development of Gpr54 gene expression in mouse brain and gonadotropin-releasing hormone neurons. Endocrinology 2010; 151(1): 312-321 [PMID: 19966188 DOI: 10.1210/en.2009-0552]

16 Castellano, J.M.; Tena-sempere M. Metabolic regulation of kisspeptin. Adv Exp Med Biol.,2013, 784:363 - 383.

17 Silvestre RA, Egido EM, Hernandez R, Marco J. Kisspeptin-13 inhibits insulin secretion without affecting glucagon or somatostatin release: study in the perfused rat pancreas. $\boldsymbol{J}$ Endocrinol 2008; 196(2): 283-290 [PMID: 18252951 DOI: $10.1677 / \mathrm{JOE}-07-0454]$

18 Song WJ, Mondal P, Wolfe A, Alonso LC, Stamateris R, Ong BW, Lim OC, Yang KS, Radovick S, Novaira HJ, Farber EA, Farber
CR, Turner SD, Hussain MA. Glucagon regulates hepatic kisspeptin to impair insulin secretion. Cell Metab 2014; 19(4): 667-681 [PMID: 24703698 PMCID: PMC4058888 DOI: 10.1016/j.cmet.2014.03.005]

19 Schwetz TA, Reissaus CA, Piston DW. Differential stimulation of insulin secretion by GLP-1 and Kisspeptin-10. PLoS One 2014; 9(11): e113020 [PMID: 25401335 PMCID: PMC4234631

DOI:

10.1371/journal.pone.0113020]

20 Panidis D, Rousso D, Koliakos G, Kourtis A, Katsikis I, Farmakiotis D, Votsi E, DiamantiKandarakis E. Plasma metastin levels are negatively correlated with insulin resistance and free androgens in women with polycystic ovary syndrome. Fertil Steril 2006; 85(6): 1778-1783 [PMID: 16650418 DOI: 10.1016/j.fertnstert.2005.11.044]

21 Andreozzi, F.; Mannino, G .C.; Mancuso, E. Plasma kisspeptin levels are associated with insulin secretion in non-diabetic individuals. Plos one, 2017,12(6): e 0179834.

22 Tolson KP, Garcia C, Yen S, Simonds S, Stefanidis A, Lawrence A, Smith JT, Kauffman AS. Impaired kisspeptin signaling decreases metabolism and promotes glucose intolerance and obesity. J Clin Invest 2014; 124(7): 3075-3079 [PMID: 24937427 PMCID: PMC4071390 DOI: $10.1172 / J C I 71075]$

23 Poudyal H, Campbell F, Brown L. Olive leaf extract attenuates cardiac, hepatic, and metabolic changes in high carbohydrate-, high fat-fed rats. $\boldsymbol{J}$ Nutr 2010; 140(5): 946-953 [PMID: 20335636 DOI: 10.3945/jn.109.117812]

24 Novelli EL, Diniz YS, Galhardi CM, Ebaid GM, Rodrigues HG, Mani F, Fernandes AA, Cicogna AC, Novelli Filho JL. Anthropometrical parameters and markers of obesity in rats. Lab Anim 2007; 41(1): 111119 [PMID: 17234057 DOI: 10.1258/002367707779399518]

25 Yang S, Ji B, Undar A, Zahn JD. Microfluidic devices for continuous blood plasma separation and analysis during pediatric cardiopulmonary bypass procedures. $\boldsymbol{A S A I O ~} \boldsymbol{J}$ 2006; 52(6): 698-704 [PMID: 17117061 DOI: 10.1097/01.mat.0000249015.76446.40] 
26 Tietz, N.W.; Cook, T.; Mcniven, M.A. Clinical Guide to Laboratory Tests; W.B. Saunders: Philadelphia,1995; pp509-512.

27 Temple R, Clark PM, Hales CN. Measurement of insulin secretion in type 2 diabetes: problems and pitfalls. Diabet Med 1992; 9(6): 503-512 [PMID: 1643797]

28 Matthews DR, Hosker JP, Rudenski AS, Naylor BA, Treacher DF, Turner RC. Homeostasis model assessment: insulin resistance and beta-cell function from fasting plasma glucose and insulin concentrations in man. Diabetologia 1985; 28(7): 412-419 [PMID: 3899825]

29 Sun G, Bishop J, Khalili S, Vasdev S, Gill V, Pace D, Fitzpatrick D, Randell E, Xie YG, Zhang H. Serum visfatin concentrations are positively correlated with serum triacylglycerols and down-regulated by overfeeding in healthy young men. Am J Clin Nutr 2007; 85(2): 399-404 [PMID: 17284735 DOI: 10.1093/ajen/85.2.399]

30 Mor F, Sengul O, Topsakal S, Kilic MA, Ozmen O. Diabetogenic Effects of Ochratoxin A in Female Rats. Toxins (Basel) 2017; 9(4) [PMID: 28422066 PMCID: PMC5408218 DOI: 10.3390/toxins9040144]

31 Robertson DM, Foulds LM, Fry RC, Cummins JT, Clarke I. Circulating half-lives of folliclestimulating hormone and luteinizing hormone in pituitary extracts and isoform fractions of ovariectomized and intact ewes. Endocrinology 1991; 129(4): 1805-1813 [PMID: 1915069 DOI: 10.1210/endo-129-4$\underline{1805]}$

32 March, C.M.; Goebelsmann, U.; Nakumara, R.M.; Mishell, D.R. Roles of estradiol and progesterone in eliciting the midcycle luteinizing hormone and follicle-stimulating hormone surges. J. Clin. Endocrinol. Metab., 1979, 49: 507- 513.

33 Hukkeri V.I.; Jaiprakash, B.; Lavhale, M.S. Hepatoprotective activity of Anthus excelsa Roxb. Leaf extracts on experimental liver damage in rats. J. Pharmacogn.,2002, 11: 120-128.

34 Fossati P, Prencipe L. Serum triglycerides determined colorimetrically with an enzyme that produces hydrogen peroxide. Clin Chem 1982; 28(10): 2077-2080 [PMID: 6812986]

35 Albers, J.J.; Warnick, G.R.; Cheung, M.C. Quantification of high density lipoproteins. Lipids, 1978, 13:926 - 932. .

36 Friedewald,W.T.; Levy,R.I.;Fredrickson,D.S. Estimation of the concentration of low density lipoprotein cholesterol in plasma, without use of the preparative ultracentrifuge. Clin Chem., 1972, 18:499 - 502.

37 Altunkaynak, Z. Effects of high fat diet induced obesity on female rat livers (A histochemical study). Eur. J. Gen. Med., 2005, 2(3):100-109.

38 Kleiner DE, Brunt EM, Van Natta M, Behling C, Contos MJ, Cummings OW, Ferrell LD, Liu YC, Torbenson MS, Unalp-Arida A, Yeh M, McCullough AJ, Sanyal AJ, Nonalcoholic Steatohepatitis Clinical Research N. Design and validation of a histological scoring system for nonalcoholic fatty liver disease. Hepatology 2005; 41(6): 1313-1321 [PMID: 15915461 DOI: 10.1002/hep.20701]

39 Zhao CY, Jiang LL, Li L, Deng ZJ, Liang BL, $\mathrm{Li}$ JM. Peroxisome proliferator activated receptor-gamma in pathogenesis of experimental fatty liver disease. World $\boldsymbol{J}$ Gastroenterol 2004; 10(9): 1329-1332 [PMID: 15112352 PMCID: PMC4622776]

40 Sjoholm, A.; Nystrom, T. Inflammation and the etiology of type 2 diabetes. Diab. Metabol. Res. and Rev.,2006, 22: 4 - 10.

41 Eisinger K, Liebisch G, Schmitz G, Aslanidis C, Krautbauer S, Buechler C. Lipidomic analysis of serum from high fat diet induced obese mice. Int J Mol Sci 2014; 15(2): 29913002 [PMID: 24562328 PMCID: PMC3958895 DOI: 10.3390/ijms15022991]

42 Estrany ME, Proenza AM, Llado I, Gianotti M. Isocaloric intake of a high-fat diet modifies adiposity and lipid handling in a sex dependent manner in rats. Lipids Health Dis 2011; 10: 52 [PMID: 21486445 PMCID: PMC3095551 DOI: 10.1186/1476-511X-10-52]

43 Estrany ME, Proenza AM, Gianotti M, Llado I. High-fat diet feeding induces sex-dependent changes in inflammatory and insulin sensitivity profiles of rat adipose tissue. Cell Biochem 
Funct 2013; 31(6): 504-510 [PMID: 23112138 DOI: $10.1002 /$ cbf.2927]

44 Nickelson KJ, Stromsdorfer KL, Pickering RT, Liu TW, Ortinau LC, Keating AF, Perfield JW, 2nd. A comparison of inflammatory and oxidative stress markers in adipose tissue from weight-matched obese male and female mice. Exp Diabetes Res 2012; 2012: 859395 [PMID: 22778716 PMCID: PMC3384924 DOI: 10.1155/2012/859395]

45 Kurek K, Piotrowska DM, Wiesiolek-Kurek P, Lukaszuk B, Chabowski A, Gorski J, Zendzian-Piotrowska M. Inhibition of ceramide de novo synthesis reduces liver lipid accumulation in rats with nonalcoholic fatty liver disease. Liver Int 2014; 34(7): 1074-1083 [PMID: 24106929 DOI: 10.1111/liv.12331]

46 Kamada Y, Kiso S, Yoshida Y, Chatani N, Kizu T, Hamano M, Tsubakio M, Takemura T, Ezaki H, Hayashi N, Takehara T. Estrogen deficiency worsens steatohepatitis in mice fed high-fat and high-cholesterol diet. $\boldsymbol{A m} \boldsymbol{J}$ Physiol Gastrointest Liver Physiol 2011; 301(6): G1031-1043 [PMID: 21885686 DOI: 10.1152/ajpgi.00211.2011]

47 Yatsuji, S.; Hashimoto, E.; Tobari, M. Influence of age and gender in Japanese patients with non-alcoholic steatohepatitis. Hepatol Res.,2007, 37: 1034 - 1043.

48 Dhillo WS, Murphy KG, Bloom SR. The neuroendocrine physiology of kisspeptin in the human. Rev Endocr Metab Disord 2007; 8(1): 41-46 [PMID: 17323132 DOI: 10.1007/s11154-007-9029-1]

49 Kotani M, Detheux M, Vandenbogaerde A, Communi D, Vanderwinden JM, Le Poul E, Brezillon S, Tyldesley R, Suarez-Huerta N, Vandeput F, Blanpain C, Schiffmann SN, Vassart G, Parmentier M. The metastasis suppressor gene KiSS-1 encodes kisspeptins, the natural ligands of the orphan $G$ proteincoupled receptor GPR54. J Biol Chem 2001; 276(37): 34631-34636 [PMID: 11457843 DOI: 10.1074/jbc.M104847200]

50 Horikoshi Y, Matsumoto H, Takatsu Y, Ohtaki T, Kitada C, Usuki S, Fujino M. Dramatic elevation of plasma metastin concentrations in human pregnancy: metastin as a novel placenta-derived hormone in humans. J Clin
Endocrinol Metab 2003; 88(2): 914-919 [PMID: 12574233 DOI: $10.1210 /$ jc. 2002021235]

51 Castellano JM, Gaytan M, Roa J, Vigo E, Navarro VM, Bellido C, Dieguez C, Aguilar E, Sanchez-Criado JE, Pellicer A, Pinilla L, Gaytan F, Tena-Sempere M. Expression of KiSS-1 in rat ovary: putative local regulator of ovulation? Endocrinology 2006; 147(10): 4852-4862 [PMID: 16825322 DOI: 10.1210/en.2006-0117]

52 Richard N, Galmiche G, Corvaisier S, Caraty A, Kottler ML. KiSS-1 and GPR54 genes are co-expressed in rat gonadotrophs and differentially regulated in vivo by oestradiol and gonadotrophin-releasing hormone. $\boldsymbol{J}$ Neuroendocrinol 2008; 20(3): 381-393 [PMID: $18208554 \quad$ DOI: $\quad \underline{10.1111 / j .1365-}$ 2826.2008.01653.x]

53 Zhu HJ, Li SJ, Pan H, Li N, Zhang DX, Wang LJ, Yang HB, Wu Q, Gong FY. The Changes of Serum Leptin and Kisspeptin Levels in Chinese Children and Adolescents in Different Pubertal Stages. Int J Endocrinol 2016; 2016: 6790794 [PMID: 27990162 PMCID: PMC5136392 DOI: $10.1155 / 2016 / 6790794]$

54 Vikman J, Ahren B. Inhibitory effect of kisspeptins on insulin secretion from isolated mouse islets. Diabetes Obes Metab 2009; 11 Suppl 4: 197-201 [PMID: 19817802 DOI: 10.1111/j.1463-1326.2009.01116.x]

55 Bugianesi E, Gastaldelli A, Vanni E, Gambino R, Cassader M, Baldi S, Ponti V, Pagano G, Ferrannini E, Rizzetto M. Insulin resistance in non-diabetic patients with non-alcoholic fatty liver disease: sites and mechanisms. Diabetologia 2005; 48(4): 634-642 [PMID: 15747110 DOI: $10.1007 / \mathrm{s} 00125-005-1682-\mathrm{x}]$

56 Pruszynska-Oszmalek E, Kolodziejski PA, Sassek M, Sliwowska JH. Kisspeptin-10 inhibits proliferation and regulates lipolysis and lipogenesis processes in 3T3-L1 cells and isolated rat adipocytes. Endocrine 2017; 56(1): 54-64 [PMID: 28194651 DOI: 10.1007/s12020-017-1248-y]

57 Ota, T. Obesity-Induced Inflammation and Insulin Resistance. Front Endocrinol.,2014, doi: 10.3389 . 
58 Aydin $\mathrm{M}$, Oktar S, Yonden Z, Ozturk $\mathrm{OH}$, Yilmaz B. Direct and indirect effects of kisspeptin on liver oxidant and antioxidant systems in young male rats. Cell Biochem Funct 2010; 28(4): 293-299 [PMID: 20517893 DOI: $10.1002 / \mathrm{cbf} .1656]$

59 Wouters, K.; Vangorp , P. J.; Bieghs, V. Dietary Cholesterol, Rather than Liver Steatosis, Leads to Hepatic In $\mathrm{fl}$ ammation in Hyperlipidemic Mouse Models of Nonalcoholic Steatohepatitis. Hepatology,2008, 48:474-486.

60 Sato, K.; Shirai, R.; Yamashita, T. A potent vasoconstrictor Kisspeptin-10 accelerates atherosclerosis: amelioration by its receptor GPR54 antagonist. European Heart Journal,2017, 38(1): 679.

61 Guo W, Xie W, Lei T, Hamilton JA. Eicosapentaenoic acid, but not oleic acid, stimulates beta-oxidation in adipocytes. Lipids 2005; 40(8): 815-821 [PMID: 16296400]

62 Schenk S, Saberi M, Olefsky JM. Insulin sensitivity: modulation by nutrients and inflammation. J Clin Invest 2008; 118(9): 2992-3002 [PMID: 18769626 PMCID: PMC2522344 DOI: 10.1172/JCI34260]

63 Rometo AM, Krajewski SJ, Voytko ML, Rance NE. Hypertrophy and increased kisspeptin gene expression in the hypothalamic infundibular nucleus of postmenopausal women and ovariectomized monkeys. J Clin Endocrinol Metab 2007; 92(7): 2744-2750 [PMID: 17488799 DOI: 10.1210/jc.2007-0553]

64 Navarro VM, Castellano JM, FernandezFernandez R, Barreiro ML, Roa J, SanchezCriado JE, Aguilar E, Dieguez C, Pinilla L, Tena-Sempere M. Developmental and hormonally regulated messenger ribonucleic acid expression of KiSS-1 and its putative receptor, GPR54, in rat hypothalamus and potent luteinizing hormone-releasing activity of KiSS-1 peptide. Endocrinology 2004; 145(10): 4565-4574 [PMID: 15242985 DOI: 10.1210/en.2004-0413]

65 Smith JT, Cunningham MJ, Rissman EF, Clifton DK, Steiner RA. Regulation of Kiss 1 gene expression in the brain of the female mouse. Endocrinology 2005; 146(9): 3686-
3692 [PMID: $15919741 \quad$ DOI: 10.1210/en.2005-0488]

66 Smith JT, Clay CM, Caraty A, Clarke IJ. KiSS-1 messenger ribonucleic acid expression in the hypothalamus of the ewe is regulated by sex steroids and season. Endocrinology 2007; 148(3): 1150-1157 [PMID: 17185374 DOI: 10.1210/en.2006-1435]

67 Smith JT, Dungan HM, Stoll EA, Gottsch ML, Braun RE, Eacker SM, Clifton DK, Steiner RA. Differential regulation of KiSS-1 mRNA expression by sex steroids in the brain of the male mouse. Endocrinology 2005; 146(7): 2976-2984 [PMID: 15831567 DOI: 10.1210/en.2005-0323]

68 Quennell JH, Howell CS, Roa J, Augustine RA, Grattan DR, Anderson GM. Leptin deficiency and diet-induced obesity reduce hypothalamic kisspeptin expression in mice. Endocrinology 2011; 152(4): 1541-1550 [PMID: 21325051 PMCID: PMC3206710 DOI: 10.1210/en.2010$1100]$

69 Li Q, Roa A, Clarke IJ, Smith JT. Seasonal variation in the gonadotropin-releasing hormone response to kisspeptin in sheep: possible kisspeptin regulation of the kisspeptin receptor. Neuroendocrinology 2012; 96(3): 212-221 [PMID: 22343304 DOI: $10.1159 / 000335998]$

70 Giagulli VA, Kaufman JM, Vermeulen A. Pathogenesis of the decreased androgen levels in obese men. J Clin Endocrinol Metab 1994; 79(4): 997-1000 [PMID: 7962311 DOI: 10.1210/jcem.79.4.7962311]

71 Aggerholm AS, Thulstrup AM, Toft G, Ramlau-Hansen $\mathrm{CH}$, Bonde JP. Is overweight a risk factor for reduced semen quality and altered serum sex hormone profile? Fertil Steril 2008; 90(3): 619-626 [PMID: 18068160 DOI: 10.1016/j.fertnstert.2007.07.1292]

72 Wajchenberg BL. Subcutaneous and visceral adipose tissue: their relation to the metabolic syndrome. Endocr Rev 2000; 21(6): 697-738 [PMID: 11133069 DOI: 10.1210/edrv.21.6.0415]

73 Morselli E, Fuente-Martin E, Finan B, Kim M, Frank A, Garcia-Caceres C, Navas CR, Gordillo R, Neinast M, Kalainayakan SP, Li DL, Gao Y, Yi CX, Hahner L, Palmer BF, 
Tschop MH, Clegg DJ. Hypothalamic PGClalpha protects against high-fat diet exposure by regulating ERalpha. Cell Rep 2014; 9(2): 633-645 [PMID: 25373903 PMCID: PMC4223650 DOI: 10.1016/i.celrep.2014.09.025]

74 Cockwell H, Wilkinson DA, Bouzayen R, Imran SA, Brown R, Wilkinson M. KISS 1 expression in human female adipose tissue. Arch Gynecol Obstet 2013; 287(1): 143-147 [PMID: 22899305 DOI: 10.1007/s00404-0122514-0]

75 Rafique N, Latif R. Serum kisspeptin levels in normal and overweight Saudi females and its relation with anthropometric indices. Ann Saudi Med 2015; 35(2): 157-160 [PMID: 26336023 DOI: $10.5144 / 0256-4947.2015 .157]$

76 Yerlikaya, E.; Akin, F.; Turgut, S. Relation of plasma kisspeptin levels with obesity and insulin resistance in polycystic ovary syndrome. Endocrine Abstracts,2013, 32 : 619.

77 Smith JT, Acohido BV, Clifton DK, Steiner RA. KiSS-1 neurones are direct targets for leptin in the ob/ob mouse. $\boldsymbol{J}$ Neuroendocrinol 2006; 18(4): 298-303 [PMID: 16503925 DOI: 10.1111/j.1365-2826.2006.01417.x]

78 Goodman RL, Holaskova I, Nestor CC, Connors JM, Billings HJ, Valent M, Lehman MN, Hileman SM. Evidence that the arcuate nucleus is an important site of progesterone negative feedback in the ewe. Endocrinology 2011; 152(9): 3451-3460 [PMID: 21693677 PMCID: PMC3159787 DOI: 10.1210/en.2011$\underline{0195]}$
79 Zhou Q, Chen H, Yang S, Li Y, Wang B, Chen $\mathrm{Y}, \mathrm{Wu} \mathrm{X}$. High-fat diet decreases the expression of Kiss1 mRNA and kisspeptin in the ovary, and increases ovulatory dysfunction in postpubertal female rats. Reprod Biol Endocrinol 2014; 12: 127 [PMID: 25542298 PMCID: PMC4292805 DOI: 10.1186/14777827-12-127]

80 Kotani K, Tokunaga K, Fujioka S, Kobatake T, Keno Y, Yoshida S, Shimomura I, Tarui S, Matsuzawa Y. Sexual dimorphism of agerelated changes in whole-body fat distribution in the obese. Int J Obes Relat Metab Disord 1994; 18(4): 207-202 [PMID: 8044194]

81 Macotela Y, Boucher J, Tran TT, Kahn CR. Sex and depot differences in adipocyte insulin sensitivity and glucose metabolism. Diabetes 2009; 58(4): 803-812 [PMID: 19136652 PMCID: PMC2661589 DOI: 10.2337/db081054]

82 Carroll JF, Kaiser KA, Franks SF, Deere C, Caffrey JL. Influence of BMI and gender on postprandial hormone responses. Obesity (Silver Spring) 2007; 15(12): 2974-2983 [PMID: $\quad 18198306$ DOI: 10.1038/oby.2007.355] 